ALVES R., FARIA P., SIMÃO J. (2007), Experimental characterization of a basalt from Madeira Island traditionally applied in a regional decorative mortar. J. Building Engineering13, 326-335

(September 2017). https://doi.org/10.1016/j.jobe.2017.09.004

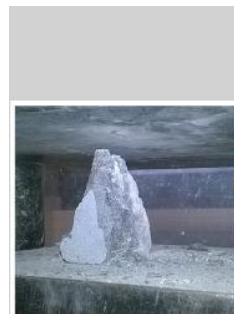

Compressive Strength

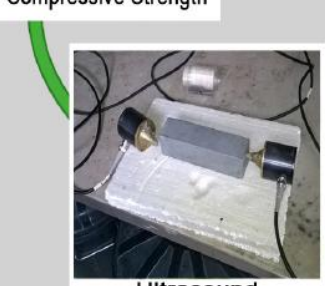

Propagation Velocity
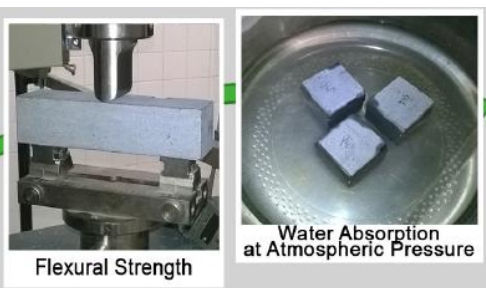

Testing

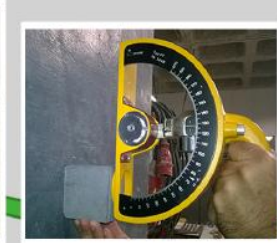

Surface Hardness

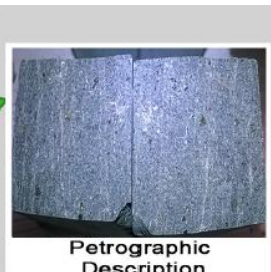

Description

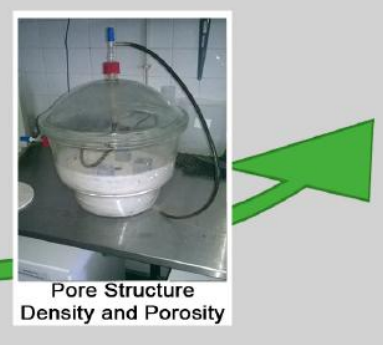

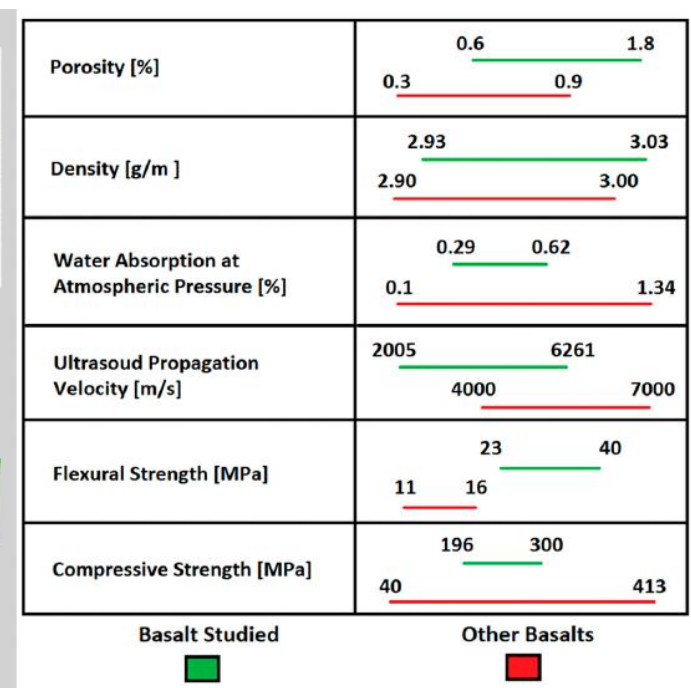

Highlights

The mechanic-physical characterization of a basalt from Madeira Island is compared to other stones

The test results of Madeira Island basalt depend on sample size

The basalt presents high strength and low water absorption

Low water absorption is adequate for exterior application but high strength limits workability

The basalt presents high potential to be used as aggregate material in coatings 


\title{
Experimental characterization of a Madeira Island basalt traditionally applied in a regional decorative mortar
}

\section{Raul Alves ${ }^{1}$, Paulina Faria ${ }^{2}$, Joaquim Simão ${ }^{3}$}

${ }^{1}$ Civil Engineer, Department of Civil Engineering, Universidade NOVA de Lisboa, Portugal, rm.alves@campus.fct.unl.pt

${ }^{2}$ Associate Professor, Department of Civil Engineering, Universidade NOVA de Lisboa and CERIS, Universidade de Lisboa, Portugal, paulina.faria@fct.unl.pt

${ }^{3}$ Assistant Professor, Department of Earth Sciences and GeoBioTec, Universidade NOVA de Lisboa, Portugal,jars@fc.unl.pt

\begin{abstract}
This study aims to understand the relationship between local materials and building techniques by characterizing a Madeira Island's basalt currently used as an aggregate in a regional mortar's coating technique named brita lavada. Laboratory tests have been carried out to characterize the basalt, extracted from a stone quarry, regarding porosity, density and mechanical strength. Results attained showed high density, compressive and flexural strength, as well as lower water absorption in comparison to other stones. Therefore, the trials justify the regional use of this basalt as an aggregate material; its characteristics justify the durability of the brita lavada coating technique, showing a good example of adequacy of an eco-efficient application of a local material.
\end{abstract}

Keywords: Madeira island, stone, basalt, characterization, eco-efficiency

\section{Introduction}

Basalt stones are used extensively as construction material in regions where they are abundant. These stones are mainly applied as aggregates to Portland cement in the production of mortars, in diverse types of concrete, as rock filling for dams and breakwaters, as material for railroad ballast and as highway base layers [1]. 
The geology of Madeira Island exhibits a variety of rock types used in construction, being basalt one of the most important. In Madeira Island, a specific basalt stone is currently used only as an aggregate of a typical and very common mortar and rendering building technique named brita lavada (that can be translated by "washed crushed stone"). The brita lavada coating system (Figure 1) is based on a mortar made with Portland cement, basalt gravel - with particle sizes 0-6 mm - and black pigment. The mortar is applied on the walls, as a finishing mortar, and a few hours after the application the surface is washed, leaving the gravel integrated in the black-pigmented cement paste more visible, simulating compact natural stone elements. A hypothesis for Madeiran builders to apply this stone as an aggregate for mortar coatings, namely for brita lavada building technique, should be justified by its properties.

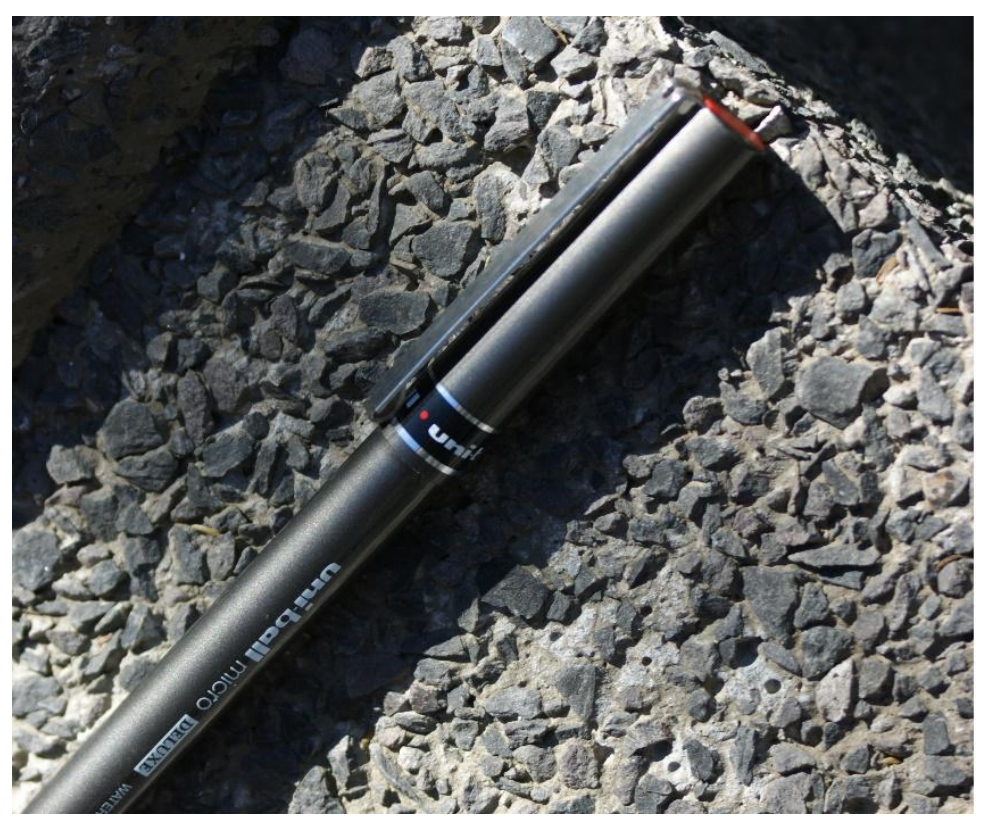

Figure 1 - Facade of brita lavada

At a regional scale the extractive, transformative and commercial sectors of natural stone industry have a large social, cultural and economic importance, for the Madeiran community since the demand for this raw material is always high [2]. Some of Madeiran stones have already been studied by Gomes and Silva [2]. These researchers studied the main physical, chemical and technological characteristics of several varieties of natural stone, from Madeira archipelago: namely trachybasalt, trachyte, picrite basalt and basalt, aiming to optimize the use of this resource in construction. The samples were submitted to various physical and mechanical tests like open porosity and apparent 
density, water absorption at atmospheric pressure, as well as compressive and flexural strength, wear and shock resistance and freeze-thaw. The tests revealed that the trachybasalt presents higher mechanical resistance and it is considered ideal for floor coverings.

Nevertheless, the basalt studied in the present work is quite different from the basalt studied by Gomes and Silva [2].

From the geological point of view the island consists mainly of eruptive stones (widely distributed) and pyroclastic materials. There are also sedimentary formations but in relatively small extent. The knowledge of the mechanical, physical and chemical properties of the basalt is critical to evaluate application possibilities, specifically for stone work and building application and even its role as an aggregate when employed to several mortars.

The lack of information about this type of basalt (applied as an aggregate in brita lavada) justifies taking destructive and non-destructive tests aimed at characterization. For a better analysis of the results it is essential to compare them to other scientific studies that characterize basalt stones, as well as other various types of natural stones used in the construction industry, in regions all over the world, such as the characterization of Ethiopian and Sardinian highlands volcanic stones used as construction materials [3], Branisca and Dobre basalts from Romania [4], Eocene basalts from northeastern Turkey [5], gabbros and basalts from northern Greece [6], physical properties of schist form Portugal [7], shales from Trás-os-Montes and Alto Douro, Portugal [8] and many others.

The crushed gravel employed as an aggregate in brita lavada presents an angular grain shape, resulting in a greater capability to adhere to the binder by comparison to rounder grain rounder grain. Bell [9] indicated that stones like basalts tend to produce angular fragments when crushed, resulting in a reduction of the workability of the mixture but, simultaneously angular fragments are considered good to produce a denser concrete or mortar. Strong and hard stones like basalts produce a higher quantity of chips when compared to weaker type of stones; although in the end they generate more quantity of fine sized particles during the crushing process [10].

Therefore, this study intends to be a contribution for a better scientific knowledge, through the mechanical and physical characterization of regional basalt, which is critical for understanding the 
behavior of the basalt as an aggregate used in brita lavada formulation and of brita lavada itself, as well as justifying the eco-efficient choice of this basalt for this specific application and building techniques in the region.

\section{Materials and methodology}

\subsection{Materials and samples}

In Madeira Island, the natural stone quarries are mainly located in the western sector of the island, in the so called Superior Volcanic Complex (SVC) [11]. The samples stone blocks used in the present work were selected from a quarry located in the Unit of Lombos (SVC1) - Phase of island volcanic overlaying on top of morphological position and, sometimes, filling the valleys related with the current morphology [11]. This is the same unit that provides the aggregates existent in brita lavada mortar.

The basalt type found in this quarry is formed by the rapid cooling of lava (predominantly alkaline), designated as alkali basalt or alkali olivine basalt lavas, which are poor in silica and rich in alcalis, characterized by phenocrystals of olivine, titanium-rich augite, plagioclase feldspar and iron oxides, and by the development of modal nepheline in the groundmass (visible at the highest magnification under the petrographic microscope) $[11,12,13]$.

For samples preparation, a basalt stone block was collected from a quarry located in Câmara de Lobos. In Figure 2 it is possible to visualize the geographical origin of the basalt and the coordinates of the place where the stone block was collected.
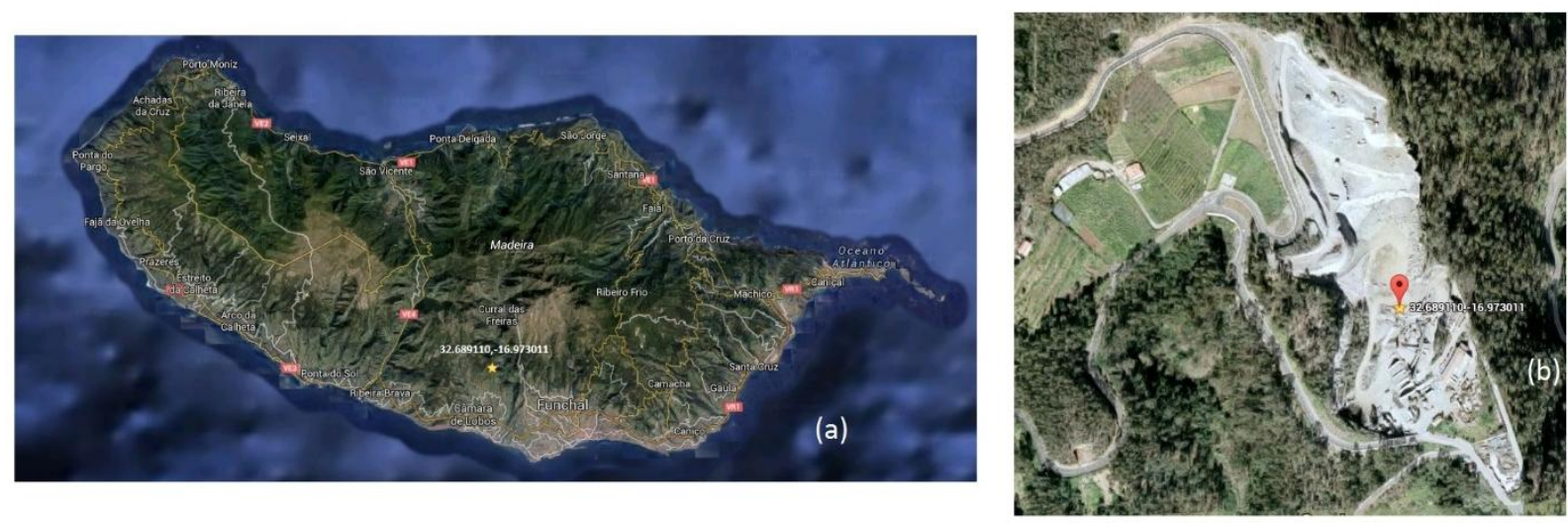
Figure 2 - Geographical origin with the location of the quarry from which the samples were taken (a) and their aerial view with the coordinates (b) [14]

The original stone block, examined macroscopically, showed some small cracks. It was not observed any kind of alteration neither granular disaggregation. Another feature of this stone is the high homogeneity, not presenting significant anisotropy. In general, and unlike most magmatic plutonic stones, volcanic magmatic stones do not have different ornamental aspects depending on the way that the block is cut [2]. Therefore, in this research it was not taken into consideration the choice criteria of the most representative reference plan.

To determine the basalt properties, a precise preparation of the samples for testing is required, namely to assess the influence of the samples size. Some samples were cut with the dimension recommended by test standards while other samples were cut according to test procedures performed by other researchers [2] to allow a direct comparison of results. Twenty-four basalt samples were prepared, all cut from the same stone block to assure identical mineralogy, texture and main physical properties. Four types of samples were cut: prismatic samples with dimension of $200 \mathrm{~mm}$ x $30 \mathrm{~mm}$ x $30 \mathrm{~mm}$ and $160 \mathrm{~mm} \times 40 \mathrm{~mm}$ x $40 \mathrm{~mm}$ and cubic samples with $70 \mathrm{~mm}$ and $40 \mathrm{~mm}$. The prismatic samples (Figure 3 a) were used for flexural strength and ultrasound propagation while the cubic samples (Figure $3 \mathrm{~b}$ ) were used for compressive strength, open porosity and apparent density, surface hardness, water absorption at atmospheric pressure and ultrasound propagation.
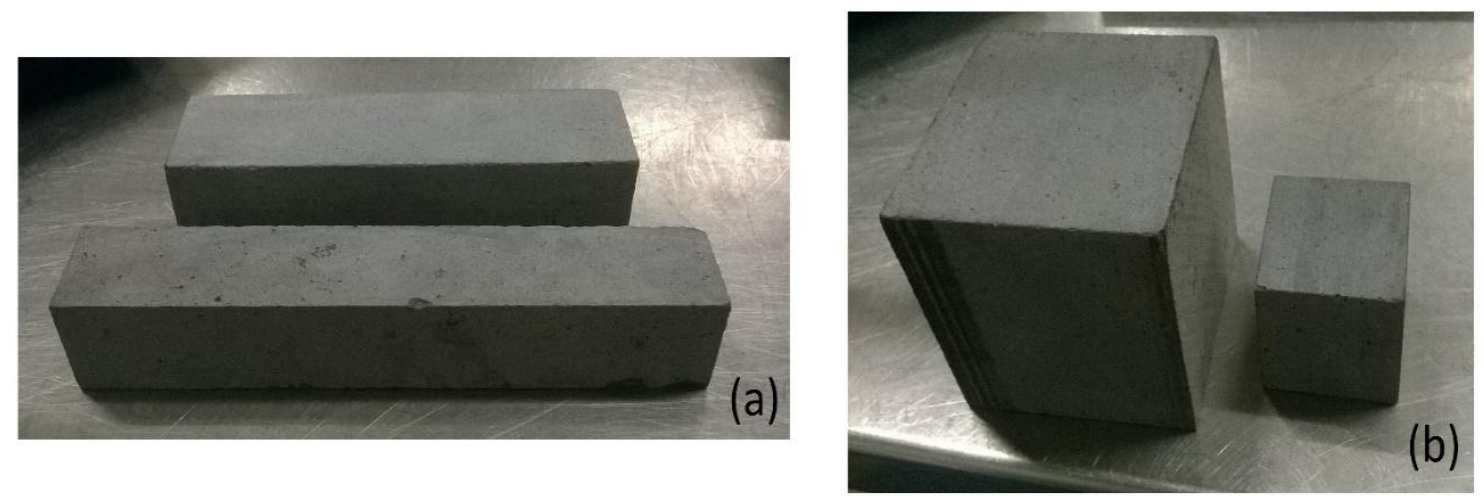

Figure 3 - Basalt sample types: (a) prismatic with $200 \mathrm{~mm}$ x $30 \mathrm{~mm}$ x $30 \mathrm{~mm}$ and $160 \mathrm{~mm}$ x $40 \mathrm{~mm}$ x $40 \mathrm{~mm}$; and (b) cubic with $70 \mathrm{~mm}$ and $40 \mathrm{~mm}$. 
The characterization consisted on a petrographic macroscopic observation of the materials using a binocular microscope Olympus model SZ51, allowing a detailed identification of the key stone minerals, texture and structure, based on EN 12407 [15], with a camera Olympus SP model - 500 UZ.

The apparent density and the open porosity of the basalt was evaluated based on EN 1936 [16], by water absorption under vacuum and weighing the specimens immersed and saturated. The EN 1936 [16] defines that the ratio between the specimens' area and volume should be between $0.08 \mathrm{~mm}^{-1}$ and $0.20 \mathrm{~mm}^{-1}$ [16]. The cubic specimens with $40 \mathrm{~mm}$ did not accomplish the EN 1936 [16] standard requirement but were still used to demonstrate the influence of the test's specimen size in the results. The water absorption at atmospheric pressure of the basalt was determined according to the methodology described in EN 13755 [17]. Each sample was weighed and then immersed in water at atmospheric pressure for 48 hours. Successive weightings were carried out until constant mass was reached (mass variation lower than $1 \%$ in $24 \mathrm{~h}$ ) with the complete saturation of the basalt samples. It should be considered that the cubic basalt samples with $40 \mathrm{~mm}$ were also not according to the parameters set by the EN 13755 [17]. Even so, these values were kept making it possible to evaluate the influence of the samples' size when determining certain properties.

The assessment of the ultrasound propagation velocity was performed following EN 14579 [18] using an Ultrasonic Pulse Velocity - Pundit Lab equipment, with a frequency of $54 \mathrm{kHz}$. The wave propagation velocity in the material is a function of its physical properties, allowing to estimate the existence of voids, cracks and density in the material [19].

The determination of the flexural and compressive strengths was obtained according to EN 12372 [20] and EN 1926 [21], respectively. For the flexural test, a Zwick Roell Z050 testing equipment was used with a load cell of 50kN and for the compressive test the FORM-TEST BETA2-3000E testing equipment with a load cell of $3000 \mathrm{kN}$ was used. The load used during the tests was applied with a uniform rate as determined by the standards EN 12372 [20] and EN 1926 [21]. After the rupture of the test's specimen by flexural test, the two halves of each sample were analysed, measuring the length of each half of the specimen to verify the breakdown surface of the specimen. 
The determination of the surface hardness was performed with a pendular Schmidt hammer OS-120, following the method described in EN 12504-2 [22]. Several test approaches were made as recommended by Aydin and Basu [23]: the hammer used was previously tested in concrete elements. The Schmidt hammer, as an index tool for non-destructive testing of concrete in situ, has been used also in stone mechanics practice, mainly for estimating the Uniaxial Compressive Strength and Young's Modulus of stone materials [24], allowing to determine the surface hardness of the stone elements [25].

According to Bell [26] the Schmidt hammer is frequently used as a mean of assessing stone hardness. Unfortunately, the Schmidt hammer is not a satisfactory method to determine the hardness of very soft or very hard stones, but there is a reasonably good correlation between Schmidt's hardness and unconfined compressive strength [26].

Table 1 summarizes all the physical and mechanical tests that were performed, identifying the number and size of the samples used for each test, in the present study and by Gomes and Silva [2].

Table 1 - Physical and mechanical tests

\begin{tabular}{|c|c|c|c|c|c|c|}
\hline \multirow{2}{*}{ Tests } & \multicolumn{3}{|c|}{ Basalt Samples Tested } & \multicolumn{3}{|c|}{ Other Samples Tested [2] } \\
\hline & Number & Size [mm] & Standards & Number & Size $[\mathrm{mm}]$ & Standards \\
\hline \multirow{2}{*}{ Open Porosity } & 6 & 70 & EN 1936 & \multirow{2}{*}{6} & \multirow{2}{*}{70} & DIN \\
\hline & 6 & 40 & EN 1936 & & & 52103 \\
\hline \multirow{2}{*}{ Apparent Density } & 6 & 70 & EN 1936 & \multirow{2}{*}{6} & \multirow{2}{*}{70} & DIN \\
\hline & 6 & 40 & EN 1936 & & & 52102 \\
\hline \multirow{2}{*}{$\begin{array}{l}\text { Water Absorption at Atmospheric } \\
\text { Pressure }\end{array}$} & 6 & 70 & EN 13755 & \multirow{2}{*}{6} & \multirow{2}{*}{70} & DIN \\
\hline & 6 & 40 & EN 13755 & & & 52103 \\
\hline \multirow{2}{*}{ Ultrasound Propagation Velocity } & 6 & 70 & EN 14579 & \multirow{2}{*}{---} & \multirow{2}{*}{--- } & \multirow{2}{*}{---} \\
\hline & 6 & $160 \times 40 \times 40$ & EN 14579 & & & \\
\hline \multirow{2}{*}{ Flexural Strength } & 6 & $160 \times 40 \times 40$ & EN 12372 & \multirow{2}{*}{6} & \multirow{2}{*}{$200 \times 30 \times 30$} & DIN \\
\hline & 6 & $200 \times 30 \times 30$ & EN 12372 & & & 52112 \\
\hline \multirow{2}{*}{ Compressive Strength } & 6 & 70 & EN 1926 & \multirow{2}{*}{6} & \multirow{2}{*}{70} & DIN \\
\hline & 6 & 40 & EN 1926 & & & 52105 \\
\hline $\begin{array}{l}\text { Surface resistance by Schmidt } \\
\text { Hammer }\end{array}$ & 6 & 70 & $\begin{array}{l}\text { EN } 12504- \\
2\end{array}$ & --- & --- & --- \\
\hline
\end{tabular}

Tables 2 and 3 show the Bell [26] and Anon [27] engineering classification of stones for porosity and dry density (Table 2) and for compressive strength (Table 3).

Table 2 - Stone classification by Bell [26] and Anon [27] - Porosity and dry density 


\begin{tabular}{|c|c|c|c|}
\hline Porosity (\%) & Classification & Density $\left(\mathbf{g} / \mathbf{m}^{\mathbf{3}}\right.$ ) & Class \\
\hline$<1$ & Very Low & Over 2.75 & 1 \\
\hline $1-5$ & Low & $2.55-2.75$ & 2 \\
\hline $5-15$ & Medium & $2.2-2.55$ & 3 \\
\hline $15-30$ & High & $1.8-2.2$ & 4 \\
\hline$>30$ & Very High & $<1.8$ & 5 \\
\hline
\end{tabular}

Table 3 - Stone classification by Bell [26] and Anon [27] - Compressive strength

\begin{tabular}{|c|c|}
\hline Strength (MPa) & Classification \\
\hline$<1.25$ & Very Weak \\
\hline $1.25-5.00$ & Weak \\
\hline $5.00-12.50$ & Moderately Weak \\
\hline $12.5-50$ & Moderately Strong \\
\hline $50-100$ & Strong \\
\hline $100-200$ & Very Strong \\
\hline$>200$ & Extremely Strong \\
\hline
\end{tabular}

\section{Results and Discussion}

All the results express the arithmetical average of the values obtained for the number of individual specimens tested. In this chapter, it is possible to visualize a comparison between the basalt studied and other different stone types.

\subsection{Petrographic Characterization}

Observations in the field reveal great lateral homogeneity of the stone at the quarry level and the stone blocks allow predicting that physical and mechanical characteristics remain uniform in the samples. On the other hand, the stone is very hard, resistant to cutting and has a very solid and compact texture with a great homogeneity between the matrix and the developed crystals.

The petrographic characterization provides relevant information to predict the behavior of natural stone. In Figure 4 it is possible to observe the macroscopic aspect of the basalt and its appearance. The stone is a basalt with compact aphanitic porphyritic texture with phenocrysts of olivine and pyroxene, hemicrystaline and melanocratic. 

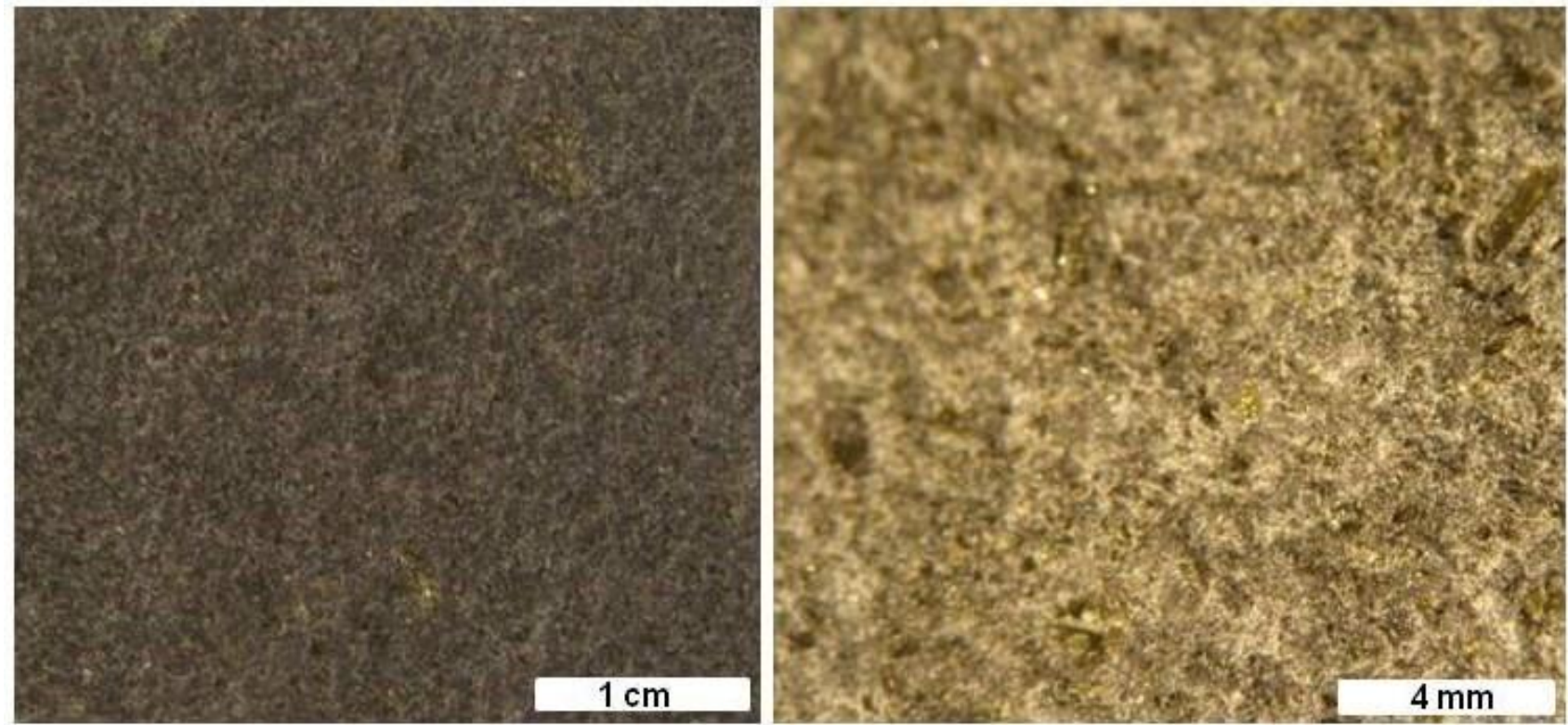

Figure 4 - Basalt samples: (a) macroscopic aspect; (b) appearance under the binocular microscope.

\subsection{Physical tests}

\subsubsection{Pore structure - density and porosity}

For this test, twelve basalt stone specimens were used: six cubic samples with $70 \mathrm{~mm}$ and other six cubic specimens with $40 \mathrm{~mm}$, visible in Figure 5.

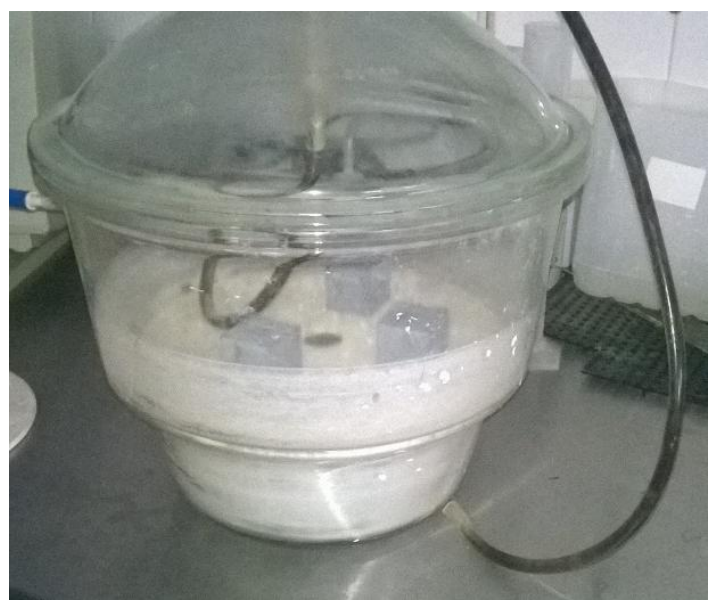

Figure 5 - Open porosity and apparent density test

In Table 4 it is possible to observe the results obtained of the open porosity and apparent density tests, namely the average, standard deviation, minimum and maximum values and coefficient of variation, based on the EN 1936 [16]. 
Table 4 - Results of open porosity and apparent density tests

\begin{tabular}{lcccc}
\hline & \multicolumn{2}{c}{ Open porosity [\%] } & \multicolumn{2}{c}{ Apparent density $\left[\mathrm{g} / \mathbf{~ m}^{\mathbf{3}}\right]$} \\
\cline { 2 - 5 } & $\mathbf{7 0} \mathbf{~} \mathbf{m}$ cube & $\mathbf{4 0} \mathbf{~ m m}$ cube & $\mathbf{7 0 ~} \mathbf{~ m}$ cube & $\mathbf{4 0 ~} \mathbf{~ m m ~ c u b e}$ \\
\hline \hline Average & 0.8 & 1.4 & 2.97 & 2.95 \\
Standard Deviation & 0.03 & 0.17 & 0.03 & 0.02 \\
Minimum Value & 0.8 & 1.2 & 2.95 & 2.93 \\
Maximum Value & 0.9 & 1.6 & 3.03 & 2.97 \\
Coefficient of Variation & 0.04 & 0.12 & 0.01 & 0.01 \\
\hline \hline
\end{tabular}

It can be observed that the dimensions selected for the samples have a huge influence on the results of open porosity: the smaller samples have higher values in comparison to the bigger ones, with a $75 \%$ difference. The percentage difference $(\%)$ is attainable through equation 1.

$$
\Delta(\%)=\frac{V_{2}-V_{1}}{V_{1}} \times 100
$$

$\mathrm{V}_{2}$ is the higher value obtained while $\mathrm{V}_{1}$ is the lower value obtained

The difference observed relates to the samples surface area; in this case, the bigger samples, with higher surface area, showed lower values of open porosity. The $70 \mathrm{~mm}$ cubes better represent the rock at its natural state, determining reliable and accurate values for this material.

Nevertheless, the sample size had less influence in the determination of apparent density since values were similar for both size samples.

From the average value of open porosity obtained in the trials and considering the proposed classification of stones provided by Bell [26], it is possible to state that the tested basalt has very low porosity, suitable to a class 5 classification scale. According to the engineering classifications from Anon [27] the open porosity of basalt is classified as low (1-5\%) for the cubic samples with $40 \mathrm{~mm}$ and very low $(<1 \%)$ for the cubic samples with $70 \mathrm{~mm}$. The low open porosity of basalt $(\leq 1 \%$ for cubes with $70 \mathrm{~mm}$ ), means that when in contact with water it will be less propitious to absorb huge amount of it when compared with a more porous stone.

When relating the results of Madeiran basalt to the values of similar stones from the island, obtained by Gomes and Silva [2], it is possible to state that amongst the stones studied the trachybasalt, designated in the island as cantaria rija - by direct translation "tough stonework" - is the one that 
presents the lowest value of open porosity $(5.09 \%)$ and the biggest value of apparent density $(2.4$ $\mathrm{g} / \mathrm{m}^{3}$ ). Even though the trachybasalt resembles basalt, in terms of results it continues to present higher open porosity and lower density when compared to the basalt in study. The samples size and number studied by Gomes and Silva [2] are equal to the ones of the present study: six cubes with 70 $\mathrm{mm}$.

Paralleling to other studies [3] the values of open porosity are very similar with other basalt stones and in some cases even lower [28], depending on the type of basalt analysed [2, 29]. Results of apparent density are consistent with the guidelines found by Engidasew [3]. These satisfactory results demonstrate a fine-grained and compact basalt stone, as opposed to other basalt stones that may have greater porosity, presenting pores due to the gas bubbles contained in the lava while it was solidifying - rapid cooling of the magma on the earth surface.

In Table 5 it is possible to observe a summary of range values for open porosity and apparent density of diverse stones adapted from Barros et al. [7]. About the results of apparent density and open porosity obtained for the trachybasalt it was not possible to obtain a range value because Gomes and Silva [2] only presented the average result from the test trials. The same happens to the following tested properties.

Table 5 - Apparent density and open porosity of various stones

\begin{tabular}{|c|c|c|c|}
\hline & Stone type & $\begin{array}{c}\text { Open Porosity } \\
\text { [\%] }\end{array}$ & $\begin{array}{c}\text { Apparent Density } \\
{\left[\mathrm{g} / \mathrm{m}^{3}\right]}\end{array}$ \\
\hline \multirow{3}{*}{ Igneous } & Basalts $[3,28,29]$ & $0.30-0.90$ & $2.90-3.00$ \\
\hline & Trachybasalt from Madeira [2] & 5.09 & 2.39 \\
\hline & Granites [29] & $0.40-1.50$ & $2.60-2.80$ \\
\hline \multirow{2}{*}{ Sedimentary } & Limestones [29] & $0.60-2.00$ & $2.60-2.80$ \\
\hline & Sandstones [30] & $0.50-40.00$ & $1.30-3.60$ \\
\hline \multirow{2}{*}{ Metamorphic } & Marbles [29] & $0.50-3.00$ & $2.70-2.80$ \\
\hline & Schists [8] & $0.30-2.30$ & $2.51-2.88$ \\
\hline
\end{tabular}

Considering the results for the basalts provided in Table 5, it can be concluded that the open porosity for the cubic samples with $70 \mathrm{~mm}$ (the dimensions defined in the EN 1936 [16] and the same used by 
other researchers that characterized basalts) barely fits the ranges $(0.8 \%)$ and that the cubic samples with $40 \mathrm{~mm}$ do not fit the ranges at all (1.4\%). Once more it is visible the impact that the size sample has when performing this type of trials. The apparent density of the values of the basalt studied fits the ranges described for the other basalts in Table 5.

Now, comparing the values obtained for other stones (also from Table 5) the basalt studied generally presents a lower range of apparent density, like marble, granite, limestone and schist. The sandstone presents higher range of apparent density. Regarding the open porosity, the range value obtained for the basalt is the lowest of all stones, followed by the granite, same as basalt, an igneous stone. The sandstone shows higher ranges of open porosity values, from all stones.

\subsubsection{Water absorption at atmospheric pressure}

Water absorption is the proportion of water able to be absorbed by a stone under specific immersion conditions. The value obtained provides some indication of the stone's performance in service, particularly its strength, durability and stain resistance [31]. For this test six cubic samples with 70 $\mathrm{mm}$ and another six cubic samples with $40 \mathrm{~mm}$ were used, visible in Figure 6.

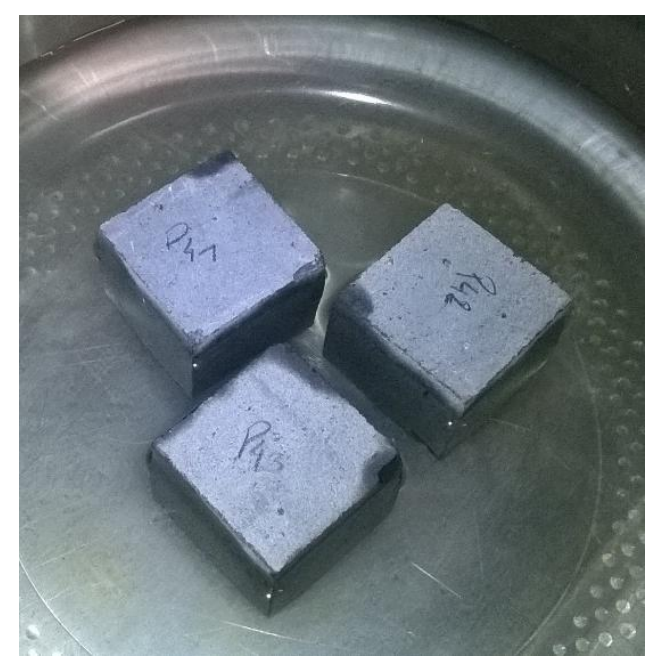

Figure 6 - Water absorption on atmospheric pressure test

In Table 6 it is possible to see the results obtained for the water absorption at atmospheric pressure, namely the average, standard deviation, minimum and maximum values, and coefficient of variation, determined using the EN 13755 [17]. 
Table 6 - Results from the water absorption at atmospheric pressure test

\begin{tabular}{lcc}
\hline & Water absorption at atmospheric pressure [\%] \\
\cline { 2 - 3 } & $\mathbf{7 0 ~} \mathbf{~ m m}$ cube & $\mathbf{4 0 ~} \mathbf{~ m m}$ cube \\
\hline \hline Average & 0.32 & 0.56 \\
Standard Deviation & 0.02 & 0.04 \\
Minumum Value & 0.29 & 0.51 \\
Maximum Value & 0.34 & 0.62 \\
Coeficient of Variation & 0.07 & 0.08 \\
\hline \hline
\end{tabular}

According to Table 6 it is possible to conclude that the basalt with cubic $70 \mathrm{~mm}$ samples have the lowest water absorption, due to size difference (higher surface area). Therefore, the dimensions selected for this test have a huge importance on the results, with differences of $75 \%$ acquired from equation 1 . The water absorption ranges, in average, from $0.32 \%$ to $0.56 \%$, which is very low $(<1 \%)$. The water absorption is related to the open porosity, i.e. the volume of open pores accessible to water within the stone and its pore size distribution. The aphanitic compact texture of the stone with good interconnection between the matrix and the stone minerals, allied to the low porosity, makes it difficult or impossible to absorb and circulate water inside the material. Since the water absorption at atmospheric pressure is low, it is expected for the basalt to also display good mechanical and chemical resistance thus, if absorbs less water it has less probability to absorb some chemical agents in the water which may alter the structure of the stone. The open porosity is very important for the stone strength for which it reduces the durability of the stone material [32].

With respect to the water absorption at atmospheric pressure, it is possible to observe, in Table 7 , a summary of the range values of various stone types, adapted from Barros et al. [7].

Table 7 - Water absorption at atmospheric pressure of diverse stones

\begin{tabular}{llc}
\hline & Stone type & Water absorption at atmospheric pressure [\%] \\
\hline \hline \multirow{2}{*}{ Igneous } & Basalts [3, 28, 26, 27] & \\
& Trachybasalt from Madeira [2] & $0.10-1.34$ \\
& Granites [33] & 2.12 \\
\multirow{2}{*}{ Sedimentary } & Limestones [33, 31] & $0.20-0.50$ \\
& Sandstones [33] & $0.20-12.00$ \\
\multirow{2}{*}{ Metamorphic } & Marbles [33] & $0.20-9.00$ \\
& Schists [8] & $0.20-0.60$ \\
\hline \hline
\end{tabular}


Through a comparative analysis of the ranges of different stones from other regions in the world it is possible to affirm that the water absorption of the basalt examined in the present study fits all ranges. In comparison to the trachybasalt from Madeira, the basalt studied is less absorbent. For this precise trial, the selected size and number of samples (six cubic samples with $70 \mathrm{~mm}$ edge) were identical to the ones tested in this study and to those examined by Gomes and Silva [2].

Given the results in Table 7 it is possible to determine that the values of the basalt in this study are within the ranges obtained by other researchers for other types of stones, even for the basalt cubic samples with $40 \mathrm{~mm}$ edge. The ranges of some stones are very large, as the cases of limestones and sandstones, as well as schists and basalts. But that is not the case of marbles and granites, with smaller ranges.

\subsubsection{Ultrasound propagation velocity}

To carry out the ultrasound propagation velocity tests, six samples with $160 \mathrm{~mm}$ x $40 \mathrm{~mm}$ x $40 \mathrm{~mm}$ and another six cubic samples with $70 \mathrm{~mm}$ were used, visible in Figure 7. It was decided to use prismatic and cubic samples to observe which one of the test specimens represents better the stone behaviour in terms of ultrasound propagation velocity. The tests were carried out according to EN 14579 [18].

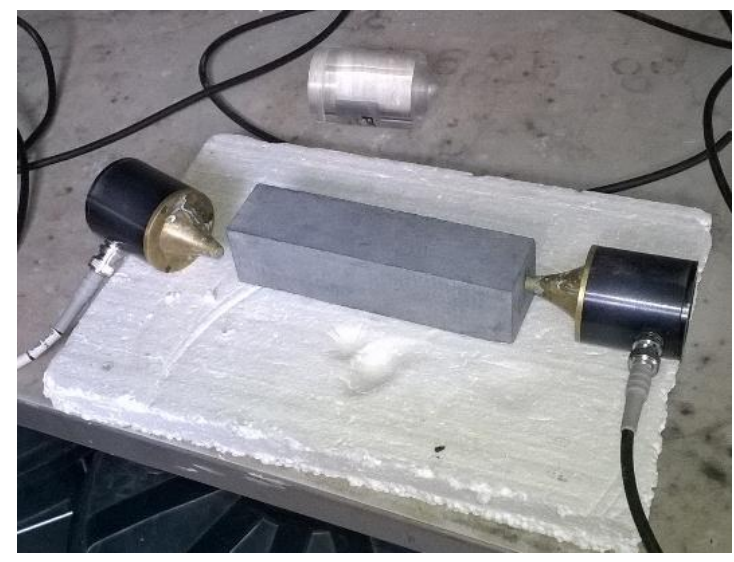

Figure 7 - Ultrasound propagation velocity test

In Table 8 it is possible to observe that the wave propagation speed is much higher for the prismatic samples in comparison to the cubic ones. The results are also according to Hasníková's [34] results. 
Table 8 - Results of the ultrasound propagation velocity

\begin{tabular}{lcc}
\hline & \multicolumn{2}{c}{ Ultrasound propagation velocity [m/s] } \\
\cline { 2 - 3 } & $\mathbf{1 6 0 \times 4 0 \times 4 0 [ \mathbf { m m } ]}$ & $\mathbf{7 0 ~} \mathbf{~ m m ~ c u b e ~}$ \\
\hline \hline Average & 6095 & 2070 \\
Standard Deviation & 106.62 & 49.05 \\
Minumum Value & 5822 & 2005 \\
Maximum Value & 6261 & 2196 \\
Coeficient of Variation & 0.02 & 0.02 \\
\hline \hline
\end{tabular}

Comparing these results to other stones' it is possible to state that the values obtained are very high, as expected by the previously achieved values on low open porosity and high apparent density tests. The ultrasound propagation velocity is related to the open porosity, pore size distribution and the way that the pores are connected.

In addition to the aforementioned, it is possible to verify that the physical and chemical aspects of the studied basalt, namely the non-weathering of the rock and its low susceptibly to interior alteration (mineral and matrix) are responsible for the high ultrasound propagation velocity.

Table 9 shows the range of values of the ultrasound propagation velocity of igneous, sedimentary and metamorphic tests performed by various researchers. For this trial, it was not possible to obtain any information related to the tests performed on Madeiran stones. For the marble stone, it was only possible to obtain a single value - average from several samples [37] - and not a range value like for other stones.

Table 9 - Ultrasound propagation velocity of some stones

\begin{tabular}{llc}
\hline & Stone type & Ultrasound propagation velocity [m/s] \\
& Basalts [3] & $4000-7000$ \\
\multirow{2}{*}{ Igneous } & Trachybasalt from Madeira & --- \\
& Granites [35] & $1956-4804$ \\
Sedimentary & Limestones [36] & $2489-2774$ \\
& Sandstones [8] & $1830-2930$ \\
Metamorphic & Marbles [37] & 4400 \\
& Schists [29] & $626-5712$ \\
\hline \hline
\end{tabular}

It may be observed that only the ultrasound propagation velocity of the test specimens with $160 \mathrm{~mm}$ x $40 \mathrm{~mm}$ x $40 \mathrm{~mm}$ fits the range of results obtained by Engidasew [3], showing that the cubic 
specimens are not adequate for the ultrasound propagation velocity test and, therefore, should not be considered, since the frequency used was too low for the cube samples.

Compared with the other stones the basalt attained a higher range of values for ultrasound propagation velocity than any other stones. The sedimentary stones presented the lowest range.

\subsection{Mechanical tests}

\subsubsection{Flexural strength}

For this test twelve basalt samples with dimensions $160 \mathrm{~mm}$ x $40 \mathrm{~mm}$ x $40 \mathrm{~mm}$ and $200 \mathrm{~mm}$ x 30 mm x 30 mm were used, visible in Figure 8.

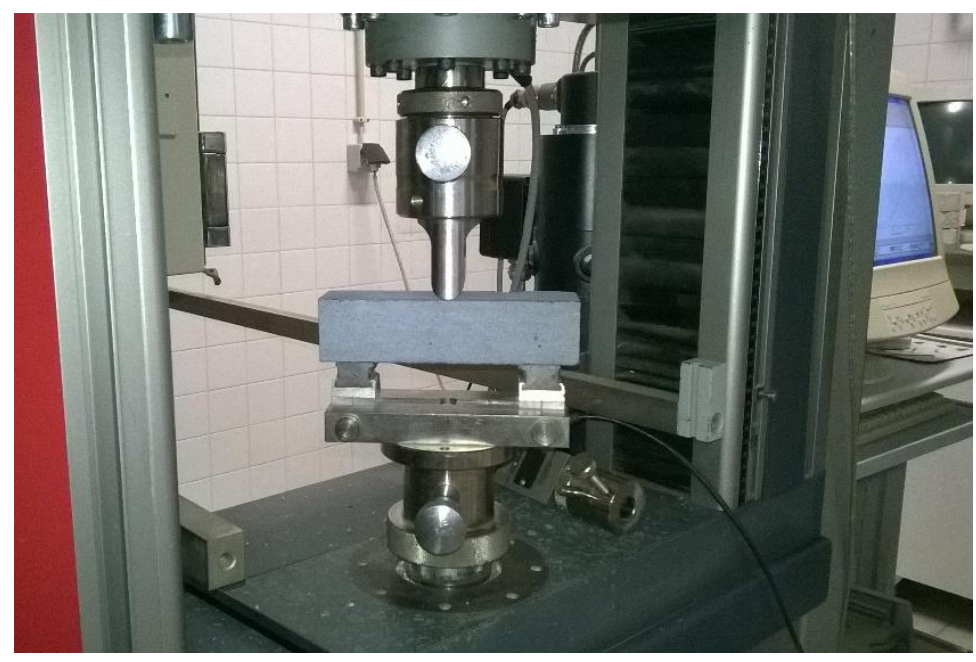

Figure 8 - Flexural strength test

Table 10 shows the results of the flexural strength, namely the average, standard deviation, minimum and maximum values, coefficient of variation and minimum expected value of the flexural strength test, based on the EN 12372 [20].

Table 10 - Results from the flexural strength test

\begin{tabular}{|c|c|c|}
\hline & \multicolumn{2}{|c|}{ Flexural strength [MPa] } \\
\hline & $200 \times 30 \times 30[\mathrm{~mm}]$ & $160 \times 40 \times 40[\mathrm{~mm}]$ \\
\hline Average & 30.47 & 37.44 \\
\hline Standard Deviation & 8.85 & 2.12 \\
\hline Minimum Value & 23.43 & 35.51 \\
\hline Maximum Value & 40.63 & 40.66 \\
\hline Coefficient of Variation & 0.29 & 0.06 \\
\hline Minimum Expected Value & 14.73 & 32.82 \\
\hline
\end{tabular}


The results of flexural strength are a little different between the two size specimens - through equation 1 the difference attained was around 23\%. Samples with $160 \mathrm{~mm}$ x $40 \mathrm{~mm}$ x $40 \mathrm{~mm}$ had a better performance during the flexural strength test, being the displayed rupture more precise and centralized in comparison to other samples.

These values relate to the geometry of the samples, meaning that, for the same material, it is more difficult to reach the rupture in a smaller sample with a larger section than in a bigger one with a smaller section.

Correlating the results of this basalt with the values of similar stones from Madeira Island, acquired by Gomes and Silva [2], it is possible to affirm that the trachybasalt presents the highest value of flexural strength resistance (18.2 MPa) of all Madeiran stones, but still far from the $37.44 \mathrm{MPa}$ reached by the studied basalt in this article.

When compared to other basaltic stones $[31,34,38]$ the values obtained are far superior, in both size specimens. In Table 11 a summary of flexural strength range values of diverse stones, adapted from Quick [31], can be observed.

Table 11 - Flexural strength of various stones.

\begin{tabular}{llc}
\hline & Stone type & \\
& & Flexural strength [MPa] \\
\hline \hline \multirow{2}{*}{ Igneous } & Basalts [31] & $11-16$ \\
& Trachybasalt from Madeira [2] & 18.2 \\
Sedimentary & Granites [31] & $8-18$ \\
& Limestones [31] & $4-20$ \\
Metamorphic & Marbles [31] & $4-12$ \\
& Slates [31] & $7-19$ \\
\hline \hline
\end{tabular}

As observed previously, in the physical test results for the trachybasalt stone type, it was only possible to observe two results from Gomes and Silva [2] experiment, namely the average and minimum expected value. For this type of trial, the dimensional size selected by Gomes and Silva [2] was $200 \mathrm{~mm}$ x $30 \mathrm{~mm}$ x $30 \mathrm{~mm}$ with an equivalent number of test specimens (six). 
Matching the results of the basalts examined in the present study with other stones previously mentioned from Madeira Island [2] and with the range obtained by Quick [31], it may be perceived that the results obtained during the experiment do not fall, by far, within the range presented for the basaltic stones in Table 11. The presented values, for the basalt studied, are highly superior with an interval of values ranging from $23 \mathrm{MPa}$ to $41 \mathrm{MPa}$, for the samples with dimensions of $200 \mathrm{~mm}$ x 30 $\mathrm{mm} \times 30 \mathrm{~mm}$ and $36 \mathrm{MPa}$ to $41 \mathrm{MPa}$, for the samples with $160 \mathrm{~mm}$ x $40 \mathrm{~mm}$ x $40 \mathrm{~mm}$.

Making a comparison to other types of stones, in terms of flexural strength, it is possible to ascertain that all the stones show lower values, except the schists that showed higher values than the basalt stone.

Regarding the type of rupture found during this test it was verified that the break shape of the stone specimen depended on the hardness and shape of the test specimen. Facing a hard-compact stone meant that the test specimen suffers a symmetrical rupture when it breaks up (Figure 8 a), always breaking in the middle of the specimen (parallel to the direction of stress). Regarding the two dimensions of the prismatic test samples, those that present a more uniform and centered rupture were the samples with dimensions of $160 \mathrm{~mm}$ x $40 \mathrm{~mm}$ x $40 \mathrm{~mm}$. Therefore, it is suggested that these dimensions ought to be used for the determination of the flexural strength. The other specimens (200 mm x $30 \mathrm{~mm}$ x $30 \mathrm{~mm}$ ) demonstrated a more "unbalance", "uncontrolled" rupture (Figure $8 \mathrm{~b}$ ).
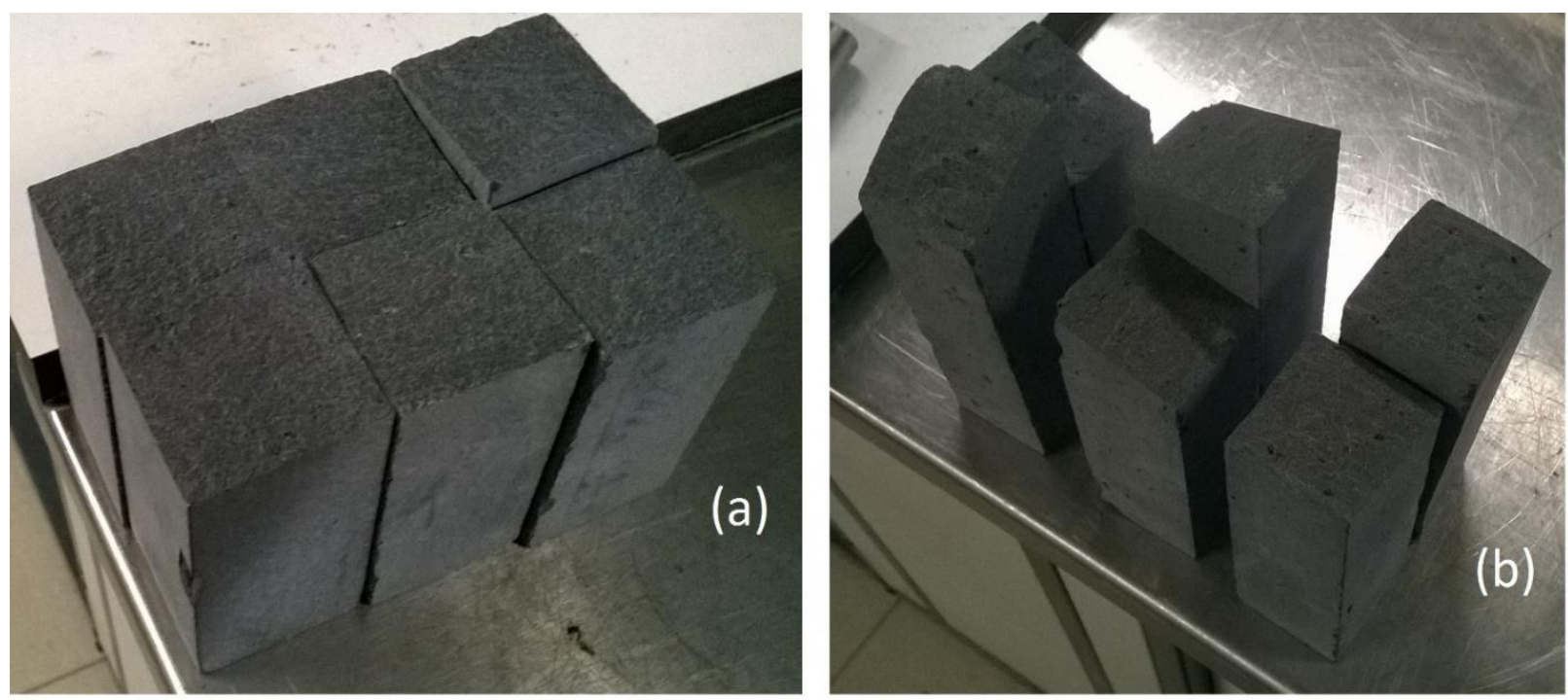

Figure 8 - Basalt samples $160 \mathrm{~mm}$ x $40 \mathrm{~mm}$ x $40 \mathrm{~mm}$ symmetrical rupture (a) and $200 \mathrm{~mm}$ x $30 \mathrm{~mm}$ x $30 \mathrm{~mm}$ with more asymmetrical rupture (b). 


\subsubsection{Compressive strength}

To determine the compressive strength, twelve samples were use: six cubes with $70 \mathrm{~mm}$ and six with $40 \mathrm{~mm}$ using the EN 1926 [21], visible in Figure 9.

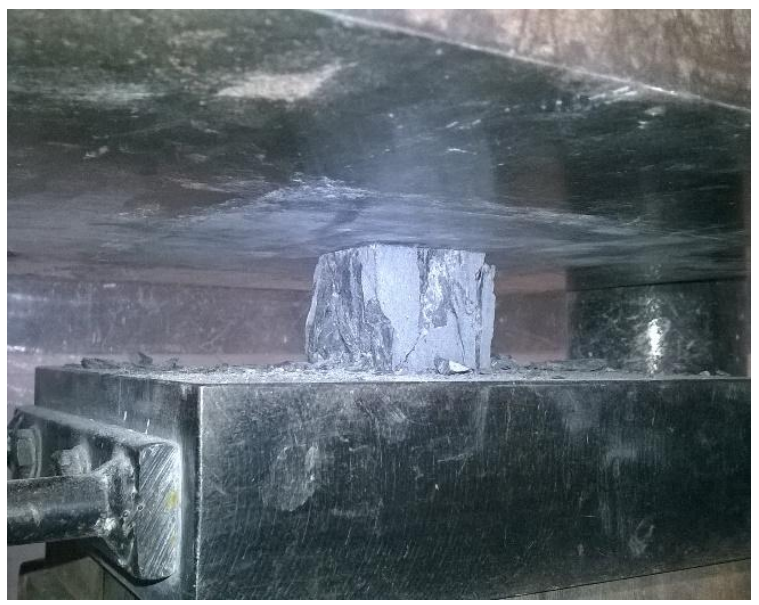

Figure 9 -Compressive strength test

Table 12 shows the results of the compressive strength, namely the average, standard deviation, minimum and maximum value, coefficient of variation and minimum expected value of this property.

Table 12 - Results from the compressive strength test

\begin{tabular}{lcc}
\hline & \multicolumn{2}{c}{ Compressive strength [MPa] } \\
\cline { 2 - 3 } & Cubes $\mathbf{7 0 ~} \mathrm{mm}$ & Cubes $\mathbf{4 0 ~} \mathrm{mm}$ \\
\hline \hline Average & 229.63 & 229.51 \\
Standard Deviation & 26.14 & 61.03 \\
Minimum Value & 196.23 & 176.28 \\
Maximum Value & 274.53 & 300.01 \\
Coefficient of Variation & 0.11 & 0.27 \\
Minimum Expected Value & 175.97 & 118.00 \\
\hline \hline
\end{tabular}

Analysing the results, it is possible to see that both size specimens show matching results; however, in terms of standard deviation the cubic samples with $70 \mathrm{~mm}$ present a lower value when compared to the cubic $40 \mathrm{~mm}$ samples. Also, the minimum expected value was higher for the cubic $40 \mathrm{~mm}$ samples. 
Although its application is limited, the unconfined compressive strength does allow comparisons to be made between stones and gives some indication of stone behaviour under more complex stress systems [39].

As done previously on the apparent density and open porosity test, it was possible to classify the compressive mechanical strength of the tested basalt, considering the proposed classification by Bell [26] and Anon [40, 27, 41]. According to the Geological Society of America, the International Association of Engineering Geology and the International Society for Rock Mechanics, the basalt in this study presents an extremely strong or a very high compressive strength.

Associating the results of the tested basalt in this article with similar stones (trachybasalt, trachyte, picrate, picrate basalt and basalt) from Madeira Island, obtained by Gomes and Silva [2], it is possible to state that none of the stones presented similar value to the basalt studied in this paper. From all the samples examined by Gomes and Silva [2] the trachybasalt showed the highest value of compressive strength resistance (114 MPa) with a minimum expected value of $90 \mathrm{MPa}$.

Concerning the compressive strength results of stones in general it is possible to observe in Table 13 a summary of range values for diverse stones adapted from Barros et al. [7], Quick [31] and Gomes and Silva [2]. The information available from Gomes and Silva [2] for this specific trial is only the average and the minimum expected value.

Table 13 - Compressive strength of some stones

\begin{tabular}{llc}
\hline & Stone Type & $\begin{array}{c}\text { Compressive strength } \\
\text { [MPa] }\end{array}$ \\
\hline \hline \multirow{3}{*}{ Igneous } & Basalts [5, 31] & $40-413$ \\
& Trachybasalt from Madeira [2] & 114 \\
Sedimentary & Granites [42, 31] & $26-310$ \\
& Limestones [5, 31] & $16-230$ \\
Metamorphic & Sandstones [5, 31] & $20-240$ \\
& Marbles [5, 31] & $40-190$ \\
& Schists [8, 43] & $31-221$ \\
\hline \hline
\end{tabular}

Comparing the results of the basalt, examined in this paper, it may be observed that these values fall within the range of results presented for basalts in Table 13 and within, or very close to, the range of 
the other stones. The range displayed by the basalt stones is generally higher than the values exhibited by the other stones.

Anon [40] tested twelve stones for compressive strength obtaining results that ranged from $176 \mathrm{MPa}$ to $300 \mathrm{MPa}$, the lower values being associated with slightly weathered basalt. According to the strength classification of Anon [40] 66.7\% of the stones were classified as extremely strong stones (over than $200 \mathrm{MPa}$ ) and the other $33.3 \%$ as very strong stones (between $100 \mathrm{MPa}$ and $200 \mathrm{MPa}$ ). This type of ranges was also visible on other basalt stones studies from various locations, such as Turkey [44], Greece [6], USA [45] and Lesotho [46]. The tested Madeiran basalt can therefore be classified as an extremely strong stone.

\subsubsection{Surface hardness}

For the determination of the surface hardness with Schmidt hammer test and due to the equipment used, six cubic samples with $70 \mathrm{~mm}$ were tested, visible in Figure 10.

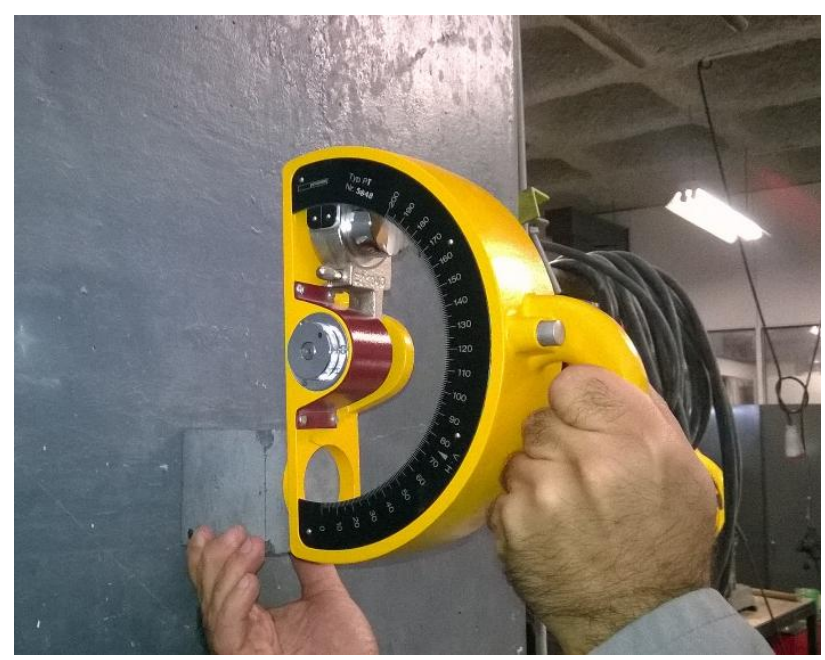

Figure 10 - Surface hardness test

Table 14 presents the results of the rebound indices obtained in the test, namely the average, standard deviation, minimum and maximum values and coefficient of variation for the surface hardness with Schmidt hammer test determined using the EN 12504-2 [22]. 
Table 14 - Results of surface hardness

\begin{tabular}{lc}
\hline & Schmidt Hammer [Vickers] \\
\cline { 2 - 2 } & $\mathbf{7 0 ~} \mathbf{~ m m}$ cube \\
\hline \hline Average & 116 \\
Standard Deviation & 7 \\
Minimum Value & 126 \\
Maximum Value & 107 \\
Coefficient of Variation & 0.06 \\
\hline \hline
\end{tabular}

This test was performed for each face of the six stone cubic samples (thirty-six values); yet the Schmidt hammer values were very approximate varying little from each one of the samples and its faces - standard deviation of 7.

In Table 15 it is possible to view a summary of surface hardness of different stones.

Table 15 - Surface hardness of some stones

\begin{tabular}{llc}
\hline & Stone type & $\begin{array}{c}\text { Schmidt Hammer } \\
\text { [Vickers] }\end{array}$ \\
\hline \hline \multirow{4}{*}{ Igneous } & Basalts [3] & 61 \\
& Trachybasalt from Madeira & --- \\
\multirow{2}{*}{ Sedimentary } & Granites [27] & $63-72$ \\
Metamorphic & Limestones [3] & $14-51$ \\
& Sandstones [3] & $22-52$ \\
& Slates [3] & 49 \\
\hline \hline
\end{tabular}

Like what happened in the ultrasound propagation velocity test, it was not possible to obtain any information related to the Schmidt hammer test for the trachybasalt because Gomes and Silva [2] did not conduct any type of test regarding the use of the Schmidt hammer for the Madeiran stones.

The values obtained for the metamorphic stones, namely gneiss and slate, do not present a range of values, like the granite, sandstone and limestone, but rather an average value like the basalt, because Engidasew [3] only defines the average values.

Comparing the results of the hardness test obtained for the basalt analysed in this study to the ones from Table 15, it is possible to observe that the value is almost two times higher than the ones 
presented. This agrees with previous results of mechanical characterization, also higher than results from other basalts.

The other stones represented in Table 15 also display a low Schmidt hammer range value, like expected since they also showed low compressive strength when examined previously on the compression strength test.

\section{Conclusion}

In this research data was collected and linked to expose the industrial performance of Madeiran basalt stones in terms of crushed coarse aggregates appropriateness. The basalt stone display a variety of textural and mineralogical characteristics, which may affect its use as a construction material and its mechanical and physical proprieties.

Basalt stones are characterized by granular massive aphanitic texture and relatively homogeneous composition that, when used in their unaltered state, are essentially sound and durable, with adequate strength for any engineering requirement [26].

Generally, with higher water absorption and porosity, and lower density, the stone tends to be less durable and less stain resistant, being more susceptible to frost and salt attack [21]. The basalt studied showed the opposite, proving to be more durable, more stain resistance and less susceptive to weathering. However, the porosity result must be treated with caution as it gives no indication of the way in which the pore space is distributed within the stone: whether there are many fine pores which increase the likelihood of absorption by capillary tension, or a smaller number of coarser pores [21]. Further characterization may be obtained by porosimetry.

Regarding the values obtained, it is concluded that the tested basalt presents high values of flexural and compressive strength, useful properties for building aggregates but too high to assure workability for building stone. Comparing with other basalts from Madeira island it is possible to observe that this stone shows higher flexural and compressive strength values. Still, the strength of a stone is an intrinsic characteristic; the effective strength of an aggregate particle is modified by its shape and size [47]. 
With this into consideration it can be concluded that the tested basalt stone from Madeira island presents as physical and mechanical characteristics: low open porosity, high apparent density, high ultrasound propagation velocity and low water absorption at atmospheric pressure, high flexural strength, high compressive strength and high rebound value (Schmidt hammer), which makes it excellent, amongst all stones, to be used as an aggregate.

These physical and mechanical characteristics show that, unlike the stones studied by Gomes and Silva [2], this basalt is extremely difficult to work with but presents good resistance and durability in contact with exterior environmental agents.

At the quarry, the stone blocks are homogeneous showing that the basalt does not change its characteristics with the direction. This is a guarantee that the good physical and mechanical properties must remain uniform in the preparation of the samples. The results of the determination of these properties were considered very good and are the reflect of the high hardness and soundness of the stone, massive aphanitic texture and strong matrix-mineral connection.

This alone justifies the fact that Madeiran builders found an appropriate and eco-efficient application for this basalt, applying it as an aggregate of mortar coatings, namely for brita lavada building technique.

The results of this study enable the understanding of properties and characteristics of basalt as a construction material. The scarcity of scientific data concerning the basalt from Madeira and its behavior for application in construction, makes the results fundamental to the understanding and evaluation of the basalt built heritage.

\section{Acknowledgments}

The authors would like to thank MSc Vitor Silva for all the help during the experimental campaign and to project DB-Heritage - Database of building materials with historical and heritage interest (PTDC/EPH-PAT/4684/2014).

\section{References}

[1] Goodman, R.E. Rock in Engineering Construction. Engineering Geology. Wiley. New York. 412 pp. 1993. 
[2] Gomes, C. S. and Silva, J. P. Natural stones from archipelago of Madeira - Cultural social and economic importance (in Portuguese). Madeira Rochas - Divulgações Científicas e Culturais. Câmara de Lobos, 1997.

[3] Engidasew, T. E. Engineering geological characterization of volcanic rocks of Ethiopian and Sardinian highlands to be used as construction materials. PhD in Soil Defense and Conservation, Environmental Vulnerability and Hydrogeological Protection. Università degli Studi di Cagliari, 2013.

[4] Ciprian, D., Grigore, B. Classification and characterization of basalts of Branisca and Dobre Romania, for capitalization. Recent Advances in Industrial and Manufacturing Technologies, pp. 64$65,2013$.

[5] Mogi, K. Experimental rock mechanics. London, Taylor \& Francis Group, 2007.

[6] Aggistalis, G. P. Alivizatos, A. S. Stamoulis, D. C. and Stournaras G. Correlating uniaxial compressive strength with Schmidt hardness, point load index, Young's modulus and mineralogy of gabbros and basalts (northern Greece). Bulletin International Association Engineering Geology, Vol. 54, pp. 3-11, 1996.

[7] Barros, R. S., Oliveira, D. V., Varum, H., Alves, C. A. S., Camões, A. Experimental characterization of physical properties of schist form Portugal. Construction and Building Materials, Vol. 50, pp. 617-630, 2014. Doi: 10.1016/j.conbuildmat.2013.10.008

[8] Noronha, F., Aires, S., Carvalho, C., Ramos, J. F., Moura, C., Moura, R., SantÓvaia, H., Ramos, V. Shales as a resource - the case of Trás-os-Montes and Alto Douro. RGAOT'11, Universidade de Trás-os-Montes e Alto Douro, 2011.

[9] Bell, F.G. and Dearman, W.R. 1988. Assessment of the durability of sandstones with illustrations from some buildings in the North of England. Engineering Geology of Ancient Works. Monuments and Historical Sites. Rotterdam. pp. 707-716, 1988.

[10] Smith, M.R. and Collis, L. Aggregates: sand, gravel and crushed Rock Aggregates for Construction Purposes. Geological Society. Engineering Geology Special Publication 17. The Geological Society. London, 2001. 
[11] Silveira, A. et al. Explanatory note of the geological map of Madeira, scale 1:50000, sheets A and B (in Portuguese). Governo Regional da Região Autónoma da Madeira. Secretaria Regional do Ambiente e Recursos Naturais and University of Madeira, 2010.

[12] Hess, P. C. Origins of igneous rocks, President and Fellows of Harvard College. pp. 276-285, 1989.

[13] Blatt, Harvey and Tracy R. Petrology, 2nd ed., Freeman. pp. 196-197, 1996.

[14] Google Maps. [Madeira Island map - geographical origin with the location of the samples tested]. [2016]. Available in https://www.google.pt/maps/place/32 ${ }^{\circ} 41^{\prime} 20.8^{\prime \prime} \mathrm{N}+16^{\circ} 58^{\prime} 22.8^{\prime \prime} \mathrm{W}$ (01.09.2016)

[15] EN 12407:2007. Natural stone test methods. Petrographic examination. CEN, Brussels.

[16] EN 1936:2008. Natural stone test methods. Determination of real density and apparent density, and of total and open porosity. CEN, Brussels.

[17] EN 13755:2008. Natural stone test methods. Determination of water absorption at atmospheric pressure. CEN, Brussels.

[18] EN 14579:2004. Natural stone test methods; Determination of sound speed propagation. CEN, Brussels.

[19] Al-Harthi, A. A., Al-Amri, R. M., Shehata, W. M. The porosity and engineering properties of vesicular basalt in Saudi Arabia. Engineering Geology, Vol. 54, pp. 313-320, 1999. Doi: 10.1016/S0013-7952(99)00050-2

[20] EN 12372:2006. Natural stone test methods. Determination of flexural strength under concentrated load. CEN, Brussels.

[21] EN 1926:2006. Natural stone test methods. Determination of uniaxial compressive strength. CEN, Brussels.

[22] EN 12504-2:2012. Testing concrete in structures; Part 2: Non-destructive testing; Determination of rebound BIGINT. CEN, Brussels.

[23] Aydin, A., Basu, A. The Schmidt hammer in rock material characterization. Engineering Geology, Vol. 81, pp. 1-14, 2005. Doi: 10.1016/j.enggeo.2005.06.006 
[24] ISRM. Suggested methods for determining hardness and abrasiveness of rocks. Rock characterization, testing and monitoring: ISRM suggested Methods. Brown E.T. editor. Oxford, Pergamon, pp. 95-6, 1981.

[25] Viles, H. A., Groudie, A. S., Grab, S., Lalley, J. The use of Schmidt hammer and equotip for rock hardness assessment in geomorphology and heritage science: a comparative analysis. Earth Surface Processes and Landforms, Vol. 36, pp. 320-333, 2010. Doi: 10.1002/esp.2040

[26] Bell, F. G. Engineering Geology. Oxford. Elsevier. Second Edition, 2007.

[27] Anon, O. H. Classification of rocks and soils for engineering geological mapping, Part 1 - Rock and soil materials. Report of the Commission of Engineering Geological Mapping, Bulletin International Association of Engineering Geology, Vol. 19, pp. 364-371, 1979.

[28] Suryawanshi, S. B and Patil, D. S. Feasibility study of basalt stone tile - a case study. International Journal of Scientific \& Engineering Research, Vol. 4 (8), pp. 1835-1838, 2013.

[29] Baglioni, A. Manuale di progettazione edilizia. The traditional materials. Milan. Hoepli, 2007 (in Italian).

[30] Kobranova, V. N. Petrophysics. Berlin, Springer-Verlag, 1989. Doi: 10.1002/crat.2170251014

[31] Quick, G. W. Selective guide to the specification of dimension stone. Discovering Stone, Vol. 1 (1), pp. 8-21, 2002.

[32] Goodman, R. E. Introduction to rock mechanics. Second edition. John Wiley \& Sons, 1989.

[33] Reis, A. C. Organization and management of constructions (in Portuguese). Lisbon, Edições Técnicas E.T.L. 2010.

[34] Hasníková, H. Testing mechanical properties of natural stones used as a building material. Engineering Mechanics, Vol. 20 (5), pp. 427-435, 2013.

[35] Mockovciakova, A., Pandula, B. Study of the relation between the static and the dynamic moduli of rocks. Metalurgija, Vol. 42 (1), pp. 37-39, 2003.

[36] Barbera, G. Barone, G. Mazzoleni, P. Scandurra, A. Laboratory measurement of ultrasound velocity during accelerated aging tests: Implication for the determination of limestone durability. 
Construction and Building Materials, Vol. 36, pp. 977-983, 2012. Doi: 10.1016/j.conbuildmat.2012.06.029

[37] Martínez-Martínez, J. Benavente, D. Gomes-Heras, M. Marco-Castaño, L. Garcia-del-Cura, M. A. Non-linear decay of building stones during freeze-thaw weathering processes. Construction and Building Materials, Vol. 38, pp. 443-454, 2013. Doi: 10.1016/j.conbuildmat.2012.07.059

[38] Lewis, M. D. Modern stone cladding: Design and installation of exterior dimension stone systems. ASTM Manual Series: MNL 21, 1995.

[39] Tsiambaos, G. and Sabatakakis, N. Considerations on strength of intact sedimentary rocks. Engineering Geology, Vol. 72, pp. 261-273, 2004. Doi: 10.1016/j.enggeo.2003.10.001

[40] Anon, O. H. The description of rock masses for engineering purposes. Engineering Group Working Party Report. Quarterly Journal of Engineering Geology, Vol. 10, pp. 43-52, 1977.

[41] Anon, O. H. Basic geotechnical description of rock masses. International Society of Rock Mechanics Commission on the Classification of Rocks and Rock Masses. International Journal of Rock Mechanics and Mining Sciences and Geomechanical Abstracts, Vol. 18, pp. 85-110, 1981.

[42] Vasconcelos, G. Experimental investigation of the mechanics of stone masonry: characterization of granites and behavior of ancient masonry shear walls. $\mathrm{PhD}$ thesis, University of Minho, 2005.

[43] Burcio, M. Structural control on the location of quarries of schist props for vines in Vila Nova de Foz Côa (in Portuguese). MSc thesis, University of Évora, 2004.

[44] Tugrul, A. and Gürpinar, O. The effect of chemical weathering on the engineering properties of Eocene basalts in northeastern Turkey. Environmental and Engineering Geoscience, Vol. 3, pp. 225234, 1997. Doi: 10.2113/gseegeosci.III.2.225

[45] Schultz, R. A. Limits on strength and deformation properties of jointed basaltic rock masses. Rock Mechanics and Rock Engineering, Vol. 28, pp. 1-15, 1995. Doi: 10.1007/BF01024770

[46] Bell, F. G. and Haskins D.R. A geotechnical overview of the Katse Dam and Transfer Tunnel, Lesotho, with a note on basalt durability. Engineering Geology, Vol. 46, pp. 175-198, 1997. Doi: 10.1016/S0013-7952(96)00110-X 
[47] Ramsay, D. M., Dhir, R. K. and Spence I. M. The role of rock and clast fabric in the physical performance of crushed-rock aggregate. Engineering Geology, Vol. 8, pp. 267-285, 1974. Doi: 10.1016/0013-7952(74)90002-7 